Emir. J. Agric. Sci. 2001. (13) : 27-32

http://www.cfs.uaeu.ac.ae/research/ejas.html

\title{
Pregnancy dependence on ovarian progesterone in the camel (Camelus dromedaries)
}

\author{
M. M. Al-Eknah, A. M. Homeida, R.O. Ramadan, F. A. Al-Modhi \& K.A. Al-Busadah \\ Camel Research Centre, College of Veterinary Medicine and Animal Resources, \\ King Faisal University, P.O. box 1757, Al-Ahsa 31982, Saudi Arabia
}

\begin{abstract}
The corpus luteum of pregnancy persists throughout the length of gestation in the dromedary camel and thus it is assumed that the ovarian progesterone is mandatory throughout gestation in this species. The objectives of this study were to test the assumption that maintenance of the pregnancy state is dependent upon ovarian progesterone throughout gestation in the dromedary camel. Thirteen parous, 10-11 months pregnant camels were used. The female camels were divided randomly into three groups. Group I animals (3) were control. Group II animals (7) were ovariectomised. Group III animals (3) were ovariectomised and received daily subcutaneous injection of $100 \mathrm{mg}$ progesterone powder prepared in sesame oil for 60 days. Jugular blood samples were taken in heparinised syringes before and after ovariectomy throughout the experimental period and plasma was obtained and stored at $-30^{\circ} \mathrm{c}$ until analyzed for progesterone and oestradiol- $17 \beta$ by radioimmunoassay. Removal of the ovaries containing corpora lutea in group II was immediately followed by abortion or premature birth. The chronic administration of progesterone succeeded in maintaining pregnancy with normal gestation length. However, fetal viability in the group maintained on progesterone was lower than in the normal controls.
\end{abstract}

Keywords: corpus luteum, progesterone, gestation, camel

\section{Introduction}

Full exploitation of the camel's production of milk and meat will only be possible when the reproductive performance is improved (Al-Eknah, 2000).

Ovulation in the camel is induced and occurs after mating (Nawito, et al, 1967; Novoa, 1970; Musa and Abusineina, 1978; Elwishy and Hemeida, 1984; Cristofori, et al, 1986). The evidence of induced ovulation is the absence of a corpus luteum formation when females are not mated (Nawito, et al, 1967; Elias, et al, 1984; Homeida et al, 1988).

Progesterone has been considered a predominately ovarian origin throughout gestation in goats, dogs, pigs, llama and alpaca, as ovariectomy at any stage of pregnancy in theste species results in abortion or premature birth (Meites et al, 1951; Mensuil du Buisson \& Dauzier, 1957; Smith et al, 1994). In other animal species such as sheep, cats, horses, a luteo-placental shift in progesterone synthesis occurs during pregnancy and therefore ovariectomy may be performed at later stages of pregnancy without inducing abortion (Demamur \& Martinet, 1955).

In the llama, which is a member of the camelidae family, pregnancy is maintained by the corpus luteum and abortion occurs if the corpus luteum is removed anytime up to 10 months of gestation. However, if the corpus luteum is removed at the eleventh month of gestation the foetus will grow to term acquiring low birth weight (SanMartin et al, 1968; Smith et al, 1994). In the dromedary and Bactrian camels, the corpus luteum of pregnancy persists throughout the length of gestation (Elwishy et al, 1981), and thus it is assumed that the ovarian progesterone is mandatory throughout gestation (Musa et al, 1976).

The objectives of this study were to test the assumption that maintenance of the pregnancy state is dependent upon progesterone throughout gestation in the dromedary camel. 


\section{Materials and Methods}

Animals

Thirteen parous female camels (Camelus dromedarius) aged 10-12 years of age and weighing 500-600 $\mathrm{Kg}$ were used. They were 10-11 months pregnant. Each animal was fed daily a mixture of barley and wheat bran (2 $\mathrm{kg}$ /day). Rhodus grass hay and water were provided ad libitum. The female camels were divided into three group; Group I (3 animals) were control (Sham surgery). Group II (7 animals) were ovariectomised. Group III. (3 animals) were ovariectomised and received daily subcutaneous injection of progesterone for 60 days.

Ovariectomy

Removal of the ovary containing one corpus luteum or more was performed in 10 camels. Anaesthesia was induced and maintained with a combination of ketamine hydrochrloride (Ketamidor 10\%, Richter Pharma, Austria) at a dose of $1 \mathrm{mg} / \mathrm{Kg} \mathrm{BW}$ and xylazine (Seton 2\%, Laboratories Calier, Spain) at a dose of $0.1 \mathrm{mg} / \mathrm{Kg} \mathrm{BW}$. After exteriorization of the ovary through incision, the ovarian vessels were identified, separated from the mesovarian ligament and grasped with a pair of haemostatic forceps. Aligature of No.0 Mersilk was placed securely around the vessels. The ovary was then excised, the hemostat was removed, and the pedicle was checked for haemorrhage before release. The preoperative and postoperative procedures were performed as previously described (Al-Eknah et al, 1993).

Collection of blood

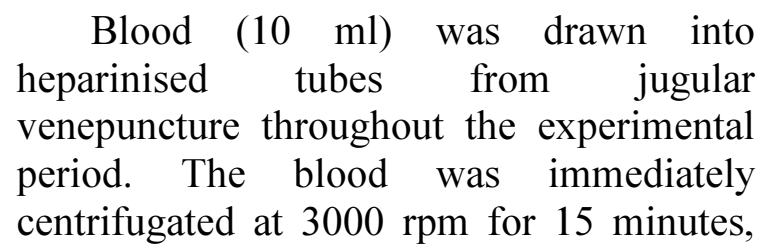

and plasma was separated and stored at $30^{\circ} \mathrm{c}$ until analysis.

Hormone assay

Progesterone concentrations were determined by radioimmunoassay (RIA) as described previously by Homeida et al, 1988). The sensitivity was $23.5 \mathrm{pg}$ per assay tube. The intra-assay coefficient of variation was $5.3 \%$ and the inter-assay coefficient of variation was $6.5 \%$.

Oestradiol-17 $\beta$ concentrations were determined by RIA as described previously (Homeida et al, 1988). The sensitivity was 3 pg per assay tube. The intra-assay coefficient of variation was $3 \%$ and the inter-assay coefficient of variation was $12.2 \%$.

Progesterone administration

$100 \mathrm{mg}$ progesterone powder (Intervet Laboratoies Ltd., England) prepared in sesame oil $(1 \mathrm{ml})$ was daily injected subcutaneously for 60 days starting one day before ovariectomy.

Determination of fetal condition

The following measurements were carried out for the newborn, aborted or premature foetuses:

- Weight

- Sex

- Fetal curved crown rump (CVR).

\section{Results}

Mean gestation length, and fetal weight and curved crown rump was significantly less in group II $(\mathrm{P}<0.01)$ than group I and III (Table 1). Removal of the ovaries containing corpora lutea (CL) in group II was followed by abortion in 6 camels and premature birth in one camel. The mean time $( \pm \mathrm{SD})$ of abortion or premature birth was 91.1 hours \pm 45.5 (Table 2). 
Emir. J. Agric. Sci. 2001. (13) : 27-32

http://www.cfs.uaeu.ac.ae/research/ejas.html

The chronic administration of with normal gestation length. However, fetal progesterone, which resulted in plasma progesterone concentrations more than 4 $\mathrm{ng} / \mathrm{mg}$, succeeded in maintaining pregnancy viability in the group maintained on progesterone was lower than in the normal controls.

Table 1. Mean $( \pm$ SD) gestation length, fetal weight, fetal curved crown rump and time of abortion after ovariectomy for the different groups

\begin{tabular}{|c|c|c|c|c|}
\hline Camel groups & $\begin{array}{l}\text { Gestation length } \\
\text { (Days) }\end{array}$ & $\begin{array}{l}\text { Fetal weight } \\
\quad(\mathrm{Kg})\end{array}$ & $\begin{array}{l}\text { Fetal CVR } \\
\quad(\mathrm{Cm})\end{array}$ & $\begin{array}{c}\text { Time of abortion } \\
\text { or premature birth } \\
\text { (h) }\end{array}$ \\
\hline Group I $(n=3)$ & $387.7 \pm 7.5 \mathrm{a}$ & $32.0 \pm 1.7 \mathrm{a}$ & $149.0 \pm 1.7 \mathrm{a}$ & \\
\hline Group II (n=7) & $317.3 \pm 8.3 b$ & $17.3 \pm 4.0 \mathrm{~b}$ & $104.0 \pm 8.0 \quad b$ & $91.1 \pm 45.5$ \\
\hline Group III $(n=3)$ & $384.7 \pm 4.5 \mathrm{a}$ & $30.7 \pm 1.2 \mathrm{a}$ & $149.3 \pm 12.9 \mathrm{a}$ & \\
\hline
\end{tabular}

$\mathrm{A}, \mathrm{b}$, means followed by a different letter for each parameter are significantly different at $\mathrm{P}<0.01$ levels

Table2. Fetal sex and viability, and site and number of corpora lutea

\begin{tabular}{|c|c|c|c|c|}
\hline Camel groups & Fetal sex & Fetal viability & Site of $\mathrm{CL}$ & No. of C \\
\hline \multicolumn{5}{|l|}{ Group I } \\
\hline 1 & $\mathrm{M}$ & Live, healthy & Right & One \\
\hline 2 & $\mathrm{M}$ & Live, healthy & Left & One \\
\hline & $\mathrm{F}$ & Live, healthy & Left & One \\
\hline \multicolumn{5}{|l|}{ Group II } \\
\hline 1 & M & Weak, premature & Left & One \\
\hline 2 & $\mathrm{~F}$ & Dead & Left & One \\
\hline 3 & M & Dead & Right & One \\
\hline 4 & $\mathrm{M}$ & Dead & Left & One \\
\hline 5 & M & Dead & Left & Two \\
\hline 6 & $\mathrm{M}$ & Dead & Right & One \\
\hline 7 & M & Dead & Right & One \\
\hline \multicolumn{5}{|l|}{ Group II } \\
\hline 1 & M & Weak, premature & Left & One \\
\hline 2 & $\mathrm{~F}$ & Dead & Left & One \\
\hline 3 & M & Dead & Right & One \\
\hline 4 & M & Dead & Left & One \\
\hline 5 & M & Dead & Left & Two \\
\hline 6 & $\mathrm{M}$ & Dead & Right & One \\
\hline 7 & M & Dead & Right & One \\
\hline
\end{tabular}

Mean ( \pm SD) peripheral plasma concentrations of progesterone and oestradiol-17 $\beta$ before ovariectomy was $3.0 \pm 0.1 \mathrm{ng} / \mathrm{mg}$ and $12.3 \pm 0.1 \mathrm{pg} / \mathrm{ml}, 3.0 \pm 0.1 \mathrm{ng} / \mathrm{mg}$ and $6.7 \pm 0.5 \mathrm{pg} / \mathrm{ml}$, and $2.9 .0 \pm 0 \mathrm{ng} / \mathrm{mg}$ and $6.7 \pm 0.7 \mathrm{pg} / \mathrm{ml}$ for group I, II and III, respectively. However, 24 hours following ovariectomy, the mean $( \pm \mathrm{SD})$ peripheral plasma concentrations of progesterone and oestradiol-17 $\beta$ was $3.1 \pm 0.1 \mathrm{ng} / \mathrm{mg}$ and $12.7 \pm 0.5 \mathrm{pg} / \mathrm{ml}, 1.7 \pm 0.1 \mathrm{ng} / \mathrm{mg}$ and $7.0 \pm 0.8 \mathrm{pg} / \mathrm{ml}$, and $3.5 \pm 0.4 \mathrm{ng} / \mathrm{mg}$ and $6.7 \pm 0.5 \mathrm{pg} / \mathrm{ml}$ for group I, II and III, respectively. 
Table 3. Mean $( \pm \mathrm{SD})$ peripheral plasma concentrations of progesterone $(\mathrm{ng} / \mathrm{ml})$ and oestradiol-17 $\beta(\mathrm{pg} / \mathrm{ml})$ in the pregnant camels after surgery

\begin{tabular}{ccccccc}
\hline $\begin{array}{c}\text { Weeks after } \\
\text { Surgery }\end{array}$ & \multicolumn{2}{c}{ Group I } & \multicolumn{2}{c}{ Group II } & \multicolumn{2}{c}{ Group II } \\
\hline 1 & $3.1 \pm 0.4$ & $12.0 \pm 3.0$ & $0.3 \pm 0.1$ & $6.0 \pm 1.0$ & $4.3 \pm 0.4$ & $6.0 \pm 2.0$ \\
2 & $2.9 \pm 0.3$ & $13.0 \pm 3.0$ & $0.2 \pm 0.1$ & $8.0 \pm 1.0$ & $4.6 \pm 0.4$ & $8.0 \pm 2.0$ \\
3 & $3.2 \pm 0.4$ & $12.0 \pm 2.0$ & $0.1 \pm 0.1$ & $6.0 \pm 2.0$ & $4.7 \pm 0.3$ & $7.0 \pm 2.0$ \\
4 & $3.1 \pm 0.4$ & $12.0 \pm 3.0$ & $0.1 \pm 0.1$ & $5.0 \pm 1.0$ & $4.6 \pm 0.3$ & $6.0 \pm 2.0$ \\
5 & $2.8 \pm 0.3$ & $11.0 \pm 3.0$ & $<0.1$ & $7.0 \pm 1.0$ & $4.8 \pm 0.3$ & $7.0 \pm 2.0$ \\
6 & $3.3 \pm 0.3$ & $12.0 \pm 2.0$ & $<0.1$ & $8.0 \pm 2.0$ & $4.7 \pm 0.4$ & $8.0 \pm 2.0$ \\
7 & $3.1 \pm 0.3$ & $11.0 \pm 2.0$ & $<0.1$ & $7.0 \pm 2.0$ & $4.6 \pm 0.3$ & $8.0 \pm 1.0$ \\
8 & $3.1 \pm 0.3$ & $13.0 \pm 3.0$ & $<0.1$ & $6.0 \pm 1.0$ & $4.7 \pm 0.3$ & $7.0 \pm 2.0$ \\
9 & $3.2 \pm 0.3$ & $12.0 \pm 2.0$ & $<0.1$ & $7.0 \pm 2.0$ & $4.7 \pm 0.4$ & $8.0 \pm 2.0$ \\
\hline
\end{tabular}

\section{Discussion}

The results demonstrate that ovariectomy in the camel caused abortion and that exogenous administration of progesterone maintained pregnancy. This indicates that the ovary is the major source of progesterone in the pregnant camel. This is consistent with the finding in the llama, which is a member of the camelidae family, since pregnancy is maintained by the corpus luteum and abortion occurs if the corpus luteum is removed anytime during gestation (San-Martin et al, 1968; Smith et al, 1994). Progesterone has been considered a predominately ovarian origin throughout gestation in some other animal species such as goats, dogs and pigs as ovariectomy at any stage of pregnancy in these species results in abortion or premature birth (Meites et al, 1951; Mensuil du Buisson \& Dauzier, 1957; Smith et al, 1994). In other animal species such as sheep, cats, horses, a luteo-placental shift in progesterone synthesis occurs during pregnancy and therefore ovariectomy may be performed at later stages of pregnancy without inducing abortion (Demamur \& Martinet, 1955). Gestation length in the camel varies between 373 and 393 days (Musa and Abusineina, 1976; Hermans and Shareha, 1990; Abdel-Raof, 1993; Al-Bisher, 1998). This variation in gestation length could be due to the method of husbandry, number of matings over the entire period of oestrus (Novoa, 1970), number of pregnancies, sex of the fetus (Agarwal et al, 1987; Arthur et al, 1982)), level of feeding (Yagil and Etzion, 1984) or season of conception (Elias et al, 1991). The accuracy in diagnosing pregnancy may help in determining the exact gestation length.

Plasma progesterone concentrations remains constantly low in the non- pregnant camel (Homeida, (1988). However, following mating at least one corpus luteum is formed secreting significant amount of progesterone (Al-Bisher, 1998). The corpus luteum remains at nearly the same size and weight throughout geatation with mean values between 3.45 and $5.13 \mathrm{ng} / \mathrm{ml}$ (Agarwal et al, 1987). Administration of progesterone to the ovariectomised camels maintained pregnancy, but viability of the fetuses born was lower than in intact animals. This was probably due to the high plasma progesterone concentrations as a result of progesterone injection, causing a degree of toxic effect on the fetuses. In this study, oestradiol-17 $\beta$ was continuously secreted during pregnancy in the camel. At mid-gestation, a rise of oestrogen concentrations has been demonstrated, suggesting continued follicular development during pregnancy (El-Wishy 
et al, 1981; Wilson, 1984; Homeida, 1990). Ovariectomy resulted in reduction but not completely abolished the secretion of oestradiol, suggesting an extra ovarian source of oestrogens, possibly the placenta. High concentrations of oestrogens in the allantoic fluid on the day of parturition have also been demonstrated in the camel, suggesting that the placenta could be a probable source of oestrogens (Elias et al, 1984). Recently, oestrogens are demonstrated to be sythesised by embryonic tissue of camel (Skidmore et al, 1994).

\section{References}

Abdel-Raouf, M. 1993. Reproduction in the dromedary (Camelus dromedarius). Egyptian Soc. Ani. Fert., Pro. $5^{\text {th }}$ Anu. Cong., January 1993, Cairo, Egypt.

Agarwal S.P., Khanna, N.D., Agarwal, V.K. and Dwarakanath, P.K. 1987. Circulating level of oestrogen and progesterone in female camels (Camelus dromedarius) during pregnancy. Theriogenology, 28, 849859.

Al-Bisher, B. E. 1998. Pregnancy and parturition in the camel (Camelus dromedarius) with particular reference to cervical dilatation. M.V.Sc. thesis, King faisal University, Saudi Arabia.

Al-Eknah, M. M. 2000. Reproduction in Old World camels. Anim. Reprod. Sci., 60-61, 583-592.

Al-Eknah, M. M., Homeida, A.M., Dafalla, E.A., Galil, A.K.A. and Al-Tahir, A.Y. 1993. Uterine activity after induction of hypocalcaemia in the ovariectomized camel (Camelus dromedarius). Vet. Res. Communi., 21, 45-50.
Arthur, G.H., Noakes, D.E. and Pearson, H. 1982. Veterinary Reproduction \& Obstetrics, Bailliere Tindall. London.

Denamur, R. and Martinet, J. 1955. Effects de l'ovariectomie chez la brebis pendant la gestation. C.R. Seances Soc. Biol. Paris 149, 2105.

Elias, E., Bedrak, E. and Yagil, R. 1984. Estradiol concentration in the serum of the one humped camel (Camelus dromedarius) during the various reproductive stages. Gen. Comp. Endocrinol., 56, 258-264.

Elias, E., Degen, A.A., and Kam, M. 1991. Effect of conception date on length of gestation in the dromedary camel (Camelus dromedarius).in the Negev Desert. Anim. Reprod. Sc., 25, 173-177.

El-Wishy, A.B, Hemeida, A B. 1984. Observations on the ovaries of slaughtered camels (Camelus dromedarius). Vet. Med. J., Giza, 32, 295-313.

El-Wishy, A.B, Hemeida, A B., Omer, M.A., Mubarak, A.M. and El-Syaed, M.A. 1981. Functional changes in the pregnant camel with special reference to fetal growth. Br. Vet. J., 137, 527-537.

Hermans, S. A. and Shareha, A. M. 1990. Reproductive performance of magrbi camel (Camelus dromedarius). Proc. Inter. Con. Camel Production and Improvement. Lybia, 1990.

Homeida, A. M. 1990. A gonadorophic-like bioactivity of the serum of pregnant camel (Camelus dromedarius). Animal Reproduction Science, 23, 327-333.

Homeida, A. M., Khalil, M.G. and Taha, A. A. 1988. Plasma concentrations of progesterone, oestrogen, testesterone 
and LH-like activity during the oestrous cycle of the camel (Camelus dromedarius). J. Reprod. Fert., 38, 593598.

Meites, J., Webster, H., Young, F., Thorp, F. and Hatch R. 1951. Effects of corpus luteum removal and replacement with progesterone on pregnancy in goats. $\mathrm{J}$. Anim. Sci., 10, 411-416.

Mesuil du Buisson, F. and Danzier, L. 1957. L' influence d'ovariectomie chez la truie penant la gestation. C.R. Soc. Biol. Paris 151, 311-315.

Musa, E.E. and Abusineina, M.E. 1976. Some observations on reproduction in the female camel (Camelus dromedarius). Acta. Vet., 26, 63-69.

Musa, E.E. and Abusineina, M.E.1978. The oestous cycle of the camel (Camelus dromedarius). Vet. Rec., 103, 556-557.

Nawito, M.F., Shalash, M.R., Hoppe, R. and Rakha, A. M. 1967. Reproduction in female camel. Nat. Res. Cent. Bull. 2, Egypt, P.82.
Novoa, C. 1970. Review: Reproduction in Camelidae. J. Reprod. Fertil., 22, 3-20.

San-Martin, M. Copaira, M., Zunigra, J. Rodriguez, R. Bustinza G. and Acosta, L. 1968. Aspects of reproduction in the alpaca. J. Reprod. Fertil., 16, 395-399.

Skidmore, J.A., Allen, W.R. and Heap, R. B. 1994. Oestrogen synthesis by the preimplantation conceptus of the onehumped camel (Camelus dromedarius). J. Reprod. Fertil., 101, 363-367.

Smith, C.L. Peter, A.T. and Pugh, D.G. 1994. Reproduction in llamas and alpacas: a review, Theriogenology, 41, 573-592.

Wilson, R.T. 1984. The camel. Longmans, London, pp. 53-102.

Yagil, R. and Etzion, Z. 1984. Enhanced reproduction in camels (Camelus dromedarius). Comp. Biochem. Physiol., 79A, 201-204. 